\title{
A Brief Analysis of the Methodology of Two Doctoral Dissertations in Ideological and Political Education
}

\author{
Wang Siqi \\ Academy of Marxism, China JiLiang University \\ Hangzhou, Zhejiang Province, 310018
}

\begin{abstract}
By comparing the methodologies used in the two doctoral thesis, it can be seen that the research embodied in these two doctoral thesis is partly same in the choice of methodology. Both articles are centered on the ideological and political education of college students. Therefore, the two are the same. They use the Marxist methodology to guide the research process and skillfully apply Marxist materialist dialectics. However, because of the different perspectives, the difference between the two is also obviously. The article analyzes the perspectives of research and problems and compares the methodology used to obtain the complexity of ideological and political education. This is a multidisciplinary subject that covers a wide range of subjects. Therefore, the researches with different perspectives are also endless, but the subject of ideological and political education also has its own backbone, that is, Marxism. So in terms of methodology, we can all see the Marxist methodology.
\end{abstract}

Keywords-Ideological and political education; Social science methodology; College students; Research perspective

\section{BRIEFLY DESCRIBE THE RESEARCH METHODOLOGY OF IDEOLOGICAL AND POLITICAL EDUCATION}

Marxist social science methodology is a creative open system. All reasonable methods created by human beings in social cognition and social practice should be actively learned and absorbed by Marxism. Marxist dialectical materialism and historical materialism are both their worldview and their methodology [1]. On this basis, it is embodied in methods based on practice, social system research methods, social contradictions analysis methods, social subject research methods, social process research methods, social cognition and evaluation methods, world history research methods, etc. In addition, there are logical and historical methods.

The discipline of ideological and political education was founded in 1984. It was established in a shorter time and intersected with multidisciplinary knowledge than other disciplines. But in general, according to Zhang Yaocan's methodology of ideological and political education research, it should be mainly "sociological paradigm" and "humanistic paradigm". That is to say, the former takes the society as the main body, and tends to study the ideological and political education to serve the society as the starting point and the foothold, while the latter believes that ideological and political education should take the individual's all-round development as the basic research perspective. However, Chen Binggong put forward the concept of "integration, duality". He believes that people and society are mutually purposeful and mutually means [2].

Therefore, we must see that the methodology of research on ideological and political education is generally in the enlightenment stage. The basic concepts of research methods and methodology of this discipline are still unclear, and the field of academic debate on subject research methods has not yet been formed. In general, the subject of ideological and political education has not appeared in different positions, doctrines, and even the so-called academic "flow" and "sect" debates.

\section{A BRIEF ANALYSIS OF THE METHODOLOGY IN THE} STUDY OF THE INSTITUTIONALIZATION OF COLLEGE STUDENTS' IDEOLOGICAL AND POLITICAL EDUCATION

\section{A. Research perspective and issues}

In the critical period of economic transition, political transformation, cultural turn, and social transformation, the party and the government pay more attention to the ideological and political education of college students [3]. The author's research is based on the perspective of multidisciplinary perspective, that is, the combination of institutional science and ideological and political education. He believes: "The relevant research on the institutionalization of ideological and political education for college students is to meet the development challenges of the world, conform to the development trend of China, and meet the development needs of college students."[4] This research has far-reaching theoretical research significance and great practical value.

On this basis, Zhang Wenxue puts forward: "We must try to solve the following three problems, namely, why do college students' ideological and political education need institutionalization, what kind of institutionalization is needed for college students' ideological and political education, and how to realize institutionalization of college students' ideological and political education." From the purpose of research, it can be divided into basic research and applied research. Basic research can add new content to the existing subject knowledge system; applied research is to solve current 
and practical problems. This paper is neither a "pure basic" study nor a "pure application" study, but a combination of the two, namely "application theory research."

\section{B. Methodology embodied in the Institute}

In the detailed analysis, the thesis takes the institutionalization of ideological and political education of college students as the research object, and combines the combination of historical investigation and realistic reflection, theoretical research and practical exploration, and with the help of basic theory and research paradigm of institutional science and ideological and political education, in-depth study of the basic issues of the significance, basis, content, characteristics and operational mechanism of the institutionalization of ideological and political education for college students in contemporary China. The general logic of his research ideas is as follows: Firstly, it fully draws on the relevant research results of institutional science to define and analyze the related concepts of institutionalization of college students' ideological and political education, and lays a theoretical foundation for the follow-up study of this subject. Secondly, it systematically sorts out the historical evolution of the institutionalization of ideological and political education between China and foreign countries.; once again, profoundly expounding the realistic demands of the institutionalization of ideological and political education for college students, On this basis, it comprehensively analyzes the predicament of the institutionalization of ideological and political education for college students. Finally, on the basis of theoretical analysis, historical investigation and realistic reflection, systematically construct the institutional system of college students' ideological and political education, explore the operational mechanism of college students' ideological and political education institutionalization, and realize the final return of the research significance of this paper [5].

Therefore, from the perspective of the article "Institutionalization of College Students' Ideological and Political Education" and the combination of historical investigation and realistic reflection, we can conclude that the methodological position held by this article is the institutional methodology and the Marxist methodology. First of all, from the object of research, the questions raised, and the ultimate goal are all around the "institution", so the institution is inseparable from the definition of core content and core concepts, and the institution emphasized in this article is "college students Ideological and political education" is the main body, Therefore, the scope of this article is in the field of interdisciplinary relationship between institution and ideological and political education, and the ultimate goal is to construct a related institutionalized system, innovate the institutionalized operational mechanism of ideological and political education in colleges and universities, and propose to implement institutionalized and feasible and guaranteed Measures. Obviously, these are based on institutional methodology. The Marxist methodology, that is, materialist dialectics, is embodied in the logic of the text or can be called argument logic. For example, in the process of defining the concept, there is no hard copy, but based on the etymological interpretation and multidisciplinary perspective of "institution", the various types of institutional existence are divided, Combined with the characteristics of ideological and political education, it divides the types of ideological and political education system in detail, specifically analyzes the relationship between ideological and political education system and ideological and political education mechanism, ideological and political education system, and finally defines the concept of institutionalization of ideological and political education in colleges and universities. It embodies the dialectical method of the text. Secondly, the article sorts out the historical evolution of the ideological and political education institutionalization, summarizes the development process and useful practices, and on this basis, expounds the appeal of the ideological and political education system and looks forward to the future. This embodies the method of unifying the history and logic. Thirdly, for the institutionalization of funny ideological and political education, this article does not simply stay on the basis of theory, but reflects and explores on the basis of practice and reality. This reflects the specific analysis method of specific problems. So in general, the methodological position held in this article is a combination of institutional methodology and Marxist methodology.

\section{A BRIEF ANALYSIS OF THE METHODOLOGY IN THE \\ STUDY OF THE IDEOLOGICAL AND POLITICAL EDUCATION Mechanism of College StUdents}

\section{A. Research perspectives and issues}

The arrival of globalization, marketization and informatization has changed the social and humanistic environment of ideological and political education in colleges and universities, and it has also put the ideological and political education of colleges and universities in a crisis of "failure". To realize the effectiveness and long-term development of college students' ideological and political education, we must pay attention to the mechanism construction, and gradually explore and improve the operational mechanism that meets the development requirements of the times. Therefore, how to improve the mechanism from the perspective of "humanization" on the basis of adhering to normativeness has become an important topic of this study.

Through the analysis of the mechanism, the connotation, elements, structure and characteristics of the mechanism and the ideological and political education mechanism, the definition of the concept of the ideological and political education mechanism of college students, the historical evolution of the ideological and political education mechanism construction of college students, investigating the current situation of ideological and political education mechanism of college students, etc., the current ideological and political education mechanism of college students should emphasize the function of various elements, the overall cooperation between the elements, and give full play to the subjective initiative of people. The study of the characteristics of the ideological and political education mechanism should not only reflect its scientific and normative nature, but also pay attention to its humanity and spirituality [6]. Since the 
founding of the People's Republic of China, although the operational mechanism of ideological and political education of Chinese college students has achieved certain results, the overall efficiency is still low. The root of the problem is that the ideological and political education concept of college students is difficult to adapt to the changes of the educational environment and the objective requirements of the development of the times, it has not yet formed a new thinking of joint education, open education, service-oriented education and comprehensive development education.

The article also analyzes how to improve the ideological and political education mechanism of college students from the macroscopic and microscopic perspectives, and expounds the Marxist people-oriented theory, needs theory and social organism theory, which has important theoretical guiding significance for the study of college students' ideological and political education mechanism, and it presents both theory and practice of construction of ideological and political education mechanism in line with the development needs of the students.

\section{B. Methodology embodied in the Institute}

In the specific research process, the ultimate goal of this paper is to construct the institutionalized system of ideological and political education for college students and to innovate the institutionalized operation mechanism of college students' ideological and political education.

The paper analyzes the article from the perspective of "the effectiveness and long-term effect of contemporary college students' ideological and political education". It is necessary to draw some relevant contents from the related disciplines such as education, sociology, management science and education, combining the theoretical basis of psychological principles and acceptance theory, and focusing on the micropsychological characteristics of contemporary college students, We can conclude that the methodological position held in this article is psychological methodology and Marxist methodology. This study takes Marxist materialist dialectics as the main methodology, examines the current situation of contemporary college students' ideological and political education from the perspective of connection and development, and comprehensively applies various research methods to systematically analyze the ideological and political education of college students, taking the theory and practice as the research goal, the unity of universality and particularity, the unity of theory and practice, the combination of quantitative analysis and qualitative analysis, and the "people-oriented" as the logical starting point, making exploratory research on enhancing the effectiveness of ideological and political education for college students. The research on the ideological and political education mechanism of college students mainly draws on the research results of ideological and political education mechanism, and analyzes the ideological and political education mechanism of Chinese college students from the perspective of theory and reality. Therefore, the research method mainly adopts systematic research method and literature reading and data analysis method, comparative research method. The embedding method can link the theoretical analysis of the ideological and political education mechanism with the operation of the educational mechanism in the real world, so that the theoretical universality of the ideological and political education mechanism of the university students can be truly revealed through specific processes such as the operation of specific mechanisms and the functioning of elements.

\section{ANALYSIS AND COMPARISON}

The research embodied in the two papers on "Institutionalization of College Students' Ideological and Political Education" and "Research on College Students' Ideological and Political Education Mechanism" is partly the same in terms of methodological choice, But because of the difference in perspective, the difference between the two is also significant. Because they are all around the ideological and political education of college students, the two are the same as the basis, that is, to guide the research process with Marxist methodology and to use Marxist materialist dialectics. This point can be drawn from the point of view of the problem, both are based on the contradiction between theory and empirical facts, from the theory, the combination of theory and practice eventually falls to the guiding practice and fully embodies the essence of Marxist methodology and seeking truth from facts. In the specific research process, the two papers have achieved the unity of history and logic, from special rise to general, from the phenomenon to sum up the law, to achieve specific analysis of specific issues.

The specific differences are obvious, because the methodologies of the two papers are limited by the limitations of the field of view. For example, "Institutionalization of College Students' Ideological and Political Education", because its vision focuses on the institutionalization of ideological and political education, and the problem that the thesis tries to solve is also how to institutionalize the ideological and political education of college students. Therefore, in the whole paper, it is discussed from the perspective of system and there is no dialectical view on the subject and object of the system. In fact, the more scientific point of view is that students and schools are the subject and object of the system, so the methodology of institutional science is not well integrated into the Marxist methodology. There is a disconnect between the two in the application process. From the perspective of institutional methodology, this article does not elaborate on the basis of institutionalization of ideological and political education for college students. As we know, the system is very important as the foundation of the superstructure, so, in the final stage of practice, that is, in the way of institutionalization, the article does not give a good answer. From this point, it can be seen that it does not have flexible application of Marxist methodology.

The article "Study on the Ideological and Political Education Mechanism of College Students" has the same problem in methodology. The ideological and political education of college students is a huge systematic project. The realization of actuality and long-term effect is affected and restricted by many factors. From the perspective of college students, the research on the methodology system of the ideological and political education mechanism construction of college students is carried out. The research on the ideological 
and political education mechanism of college students and the current specific problems have not been comprehensive. In particular, in the specific operation of the ideological and political education mechanism of college students, the classification and inter-mechanism relationship have not yet been fully clarified. While comprehensively considering the comprehensiveness, the in-depth exploration and innovation of the specific mechanism of college students' ideological and political education will be insufficient. In addition, the correspondence and connection between theoretical analysis and actual problems are not detailed enough, and it is easy to form a disguise.

\section{CONCLUSION}

Looking at the two doctoral thesis on ideological and political education, we can also see the complexity of ideological and political education itself. This is a multidisciplinary subject that covers a wide range of subjects. Therefore, the research of different perspectives is also endless, but the subject of ideological and political education also has its own backbone, that is, Marxism. So in terms of methodology, we can all see the Marxist methodology. For the two articles analyzed in this article, their proficiency in applying Marxist methodology is not very high. The study of ideological and political education from other perspectives has not achieved a high standard in this field. Therefore, even if the researchers have reached the doctoral level, there are still such problems. As a master's degree, we should pay more attention to the study and mastery of Marx's methodology, and adopt a prudent attitude in the perspective innovation, not to conduct rough research because of the novelty of perspective, regardless of the limited level of ability, which will affect the application of Marx's methodology.

\section{REFERENCES}

[1] Wang Yuliang. Marx's New World View is the World View of Dialectical Materialism [J]. Academic Research, 2012.

[2] Li Yi, Liu Hui. Giddens's Theory of Structure and Its Enlightenment to Education[J].Science Teaching,2013.

[3] Liu Xiaotong. Institutionalization of Ideological and Political Education Leads the Research of Modern University System Construction [J]. Youth and Society, 2014.

[4] Zhang Wenxue. Research on the institutionalization of ideological and political education for college students. [D]. Wuhan: China University of Geosciences. 2012.

[5] Liao Yangmei. Research on institutionalization of ideological and political education [D]. Wuhan: Central China Normal University, 2007.

[6] Hu Xinfeng. Research on the mechanism of college students' ideological and political education. [D]. Changchun: Northeast Normal University. 2014 